\title{
Pervasive transition of the Brazilian land-use system
}

\author{
David M. Lapola ${ }^{1 \star}$, Luiz A. Martinelli ${ }^{2}$, Carlos A. Peres ${ }^{3}$, Jean P. H. B. Ometto ${ }^{4}$, Manuel E. Ferreira ${ }^{5}$, \\ Carlos A. Nobre ${ }^{4}$, Ana Paula D. Aguiar ${ }^{4}$, Mercedes M. C. Bustamante 6 , Manoel F. Cardoso ${ }^{4}$, \\ Marcos H. Costa ${ }^{7}$, Carlos A. Joly ${ }^{8}$, Christiane C. Leite ${ }^{7}$, Paulo Moutinho ${ }^{9}$, Gilvan Sampaio ${ }^{4}$, \\ Bernardo B. N. Strassburg ${ }^{10,11}$ and Ima C. G. Vieira'
}

\begin{abstract}
Agriculture, deforestation, greenhouse gas emissions and local/regional climate change have been closely intertwined in Brazil. Recent studies show that this relationship has been changing since the mid 2000s, with the burgeoning intensification and commoditization of Brazilian agriculture. On one hand, this accrues considerable environmental dividends including a pronounced reduction in deforestation (which is becoming decoupled from agricultural production), resulting in a decrease of $\sim 40 \%$ in nationwide greenhouse gas emissions since 2005, and a potential cooling of the climate at the local scale. On the other hand, these changes in the land-use system further reinforce the long-established inequality in land ownership, contributing to rural-urban migration that ultimately fuels haphazard expansion of urban areas. We argue that strong enforcement of sector-oriented policies and solving long-standing land tenure problems, rather than simply waiting for market self-regulation, are key steps to buffer the detrimental effects of agricultural intensification at the forefront of a sustainable pathway for land use in Brazil.
\end{abstract}

B razil has been unique worldwide in terms of land use. Although vast areas of forests and savannahs have been converted into farmland (Fig. 1) - placing the country as a leading global producer of agricultural commodities - it still safeguards the largest tracts of native tropical vegetation on Earth, with extremely high levels of biodiversity. Patterns of land use change, which until recently exhibited the highest worldwide absolute rates of tropical deforestation, largely resulted in low-productivity cattle pastures ${ }^{2}$. Moreover, climate change issues in Brazil are inextricably related to land use and land-use change (LUC) as approximately $80 \%$ of the country's total $\mathrm{CO}_{2}$-equivalent $\left(\mathrm{CO}_{2} \mathrm{e}\right)$ emissions in 2005 were sourced from agriculture and $\mathrm{LUC}^{3}$.

Demand for farmland is the key immediate driver of LUC in Brazil, and there is little evidence that agricultural expansion is grinding to a halt ${ }^{4-7}$. In fact, Brazil holds the greatest potential for further agricultural expansion in the twenty-first century ${ }^{8}$. Understanding recent LUC patterns (Box 1) and visualizing a sustainable land-use pathway in Brazil have become highly strategic - not only for Brazilians, given that regional and global climate change, food and energy provision, and biodiversity conservation are all at stake.

This Review presents an integrated analysis and provides new insights on recent trends in the Brazilian land-use system. In the first two sections we show how Brazil's agriculture is becoming both gradually decoupled from deforestation processes and increasingly intensified and oriented to large-scale farming of trade commodities throughout the country. Next we explain the economic and political factors driving those changes. The fourth section reveals the drawbacks of those changes in aggravating the long history of inequality in land ownership. We then explore repercussions for climate change, namely for the country's greenhouse gas (GHG) emissions balance, and for the two-way interactions between climate change and land use. Finally, we discuss the meaning of sustainable land use in Brazil, and suggest how we can effectively achieve it in the near future.

\section{Decoupling agricultural expansion and deforestation}

Although agricultural expansion alone cannot explain the deforestation rates observed in the past ${ }^{9}$, both processes have long been connected in Brazil ${ }^{10,11}$. This became especially evident in the late $1990 \mathrm{~s}$, with peaks in cropland area and cattle herd size coinciding with peaks in deforestation in Amazonia and in the Cerrado region (Fig. 2).

Since the mid 2000s, annual deforestation trends began to diverge from fluctuations in cropland area and cattle herd size. Although cropland area and cattle herd continued to increase after 2004, deforestation in all Brazilian biomes plunged to the lowest rates since monitoring began. The decoupling of agricultural expansion and deforestation reported for part of the Amazon ${ }^{12}$ and elsewhere in the tropics ${ }^{13}$ therefore applies more widely to the whole of Brazil, except for some subregions such as in the northeast Cerrado, where cropland expansion is still tied to native vegetation clearing ${ }^{14,15}$.

Nevertheless, the link between agricultural expansion and deforestation has weakened rather than disappeared completely, as exemplified by the small resurgence in Amazonian deforestation in 2008, that was driven - in a much weaker way than previously seen - by increases in cropland area and cattle herd size.

\section{Towards a commoditization of the land}

From 1990 to 2011 the land area used for cropping in Brazil grew from $\sim 530,000$ to $\sim 680,000 \mathrm{~km}^{2}$. Large-scale farming of commodity crops (namely soybean, sugarcane and maize) accounted for all

\footnotetext{
'Laboratório de Ciência do Sistema Terrestre, Departamento de Ecologia, Universidade Estadual Paulista, Rio Claro, São Paulo 13506-900, Brazil, ²Centro de Energia Nuclear na Agricultura, Universidade de São Paulo, Piracicaba, São Paulo 13400-000, Brazil, ${ }^{3}$ School of Environmental Sciences, University of East Anglia, Norwich NR4 7TJ, UK, ${ }^{4}$ Centro de Ciência do Sistema Terrestre, Instituto Nacional de Pesquisas Espaciais, São José dos Campos, São Paulo 12227-010, Brazil, 5 Instituto de Estudos Sócio-Ambientais, Laboratório de Processamento de Imagens e Geoprocessamento, Universidade Federal de Goiás, Goiânia 74001-970, Brazil ' ${ }^{6}$ Departamento de Ecologia, Universidade de Brasília, Brasília, Distrito Federal 70919-970, Brazil, ${ }^{7}$ Departamento de Engenharia Agrícola, Universidade Federal de Viçosa, Viçosa, Minas Gerais 36570-000, Brazil, ${ }^{8}$ Departamento de Biologia Vegetal, Universidade Estadual de Campinas, Campinas, São Paulo 13081-970, Brazil, 9 Instituto de Pesquisa Ambiental da Amazônia, Brasília, Distrito Federal 71503-505, Brazil, ${ }^{10}$ International Institute for Sustainability, Rio de Janeiro 22460-320, Brazil, "Departamento de Geografia, Pontifícia Universidade Católica do Rio de Janeiro, Rio de Janeiro 22451-900, Brazil, ${ }^{12}$ Museu Paraense Emílio Goeldi, Belém, Pará 66040-170, Brazil.*e-mail: dmlapola@rc.unesp.br
} 

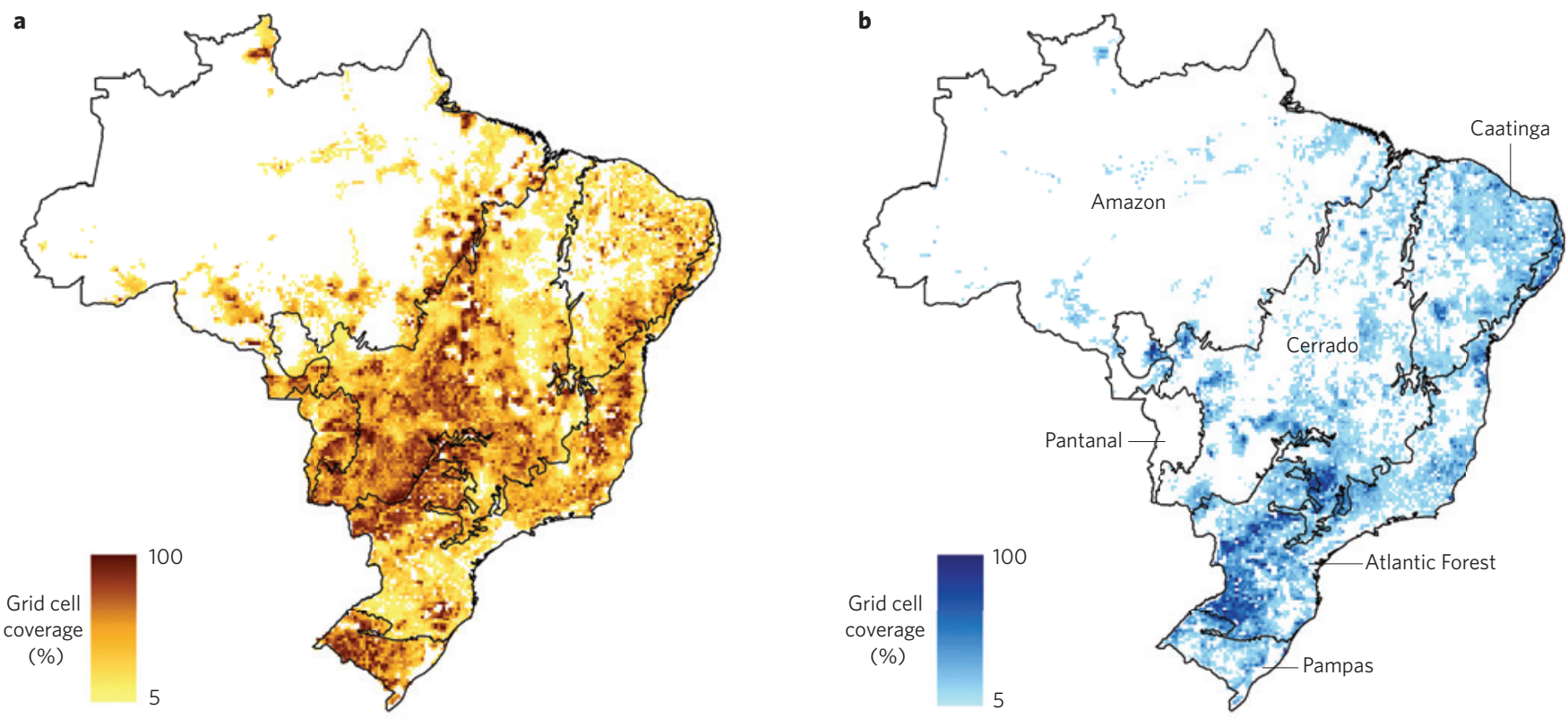

Figure 1 | Spatial distribution of agriculture in Brazilian biomes in 2000. a, Pastures. b, Croplands. Data from ref. 88 . Grid cell size is $5 \times 5$ arcmin.

of that increase (Fig. 2b). By 1990, the area occupied by these monocultures represented $53 \%$ of all cultivated area, and 21 years later this proportion increased to $70 \%$. Large-scale commodity farming represented $83 \%$ (2011 US\$84 billion) of the country's gross crop production value in $2011^{16}$. Contrastingly, although representing less than $20 \%$ of the gross value of crop production and occupying only $24 \%$ of the country's farmland, smallholder agriculture is responsible for a large fraction of the production of staple foods in Brazil ${ }^{17}$. The area cultivated with traditional staple crops such as rice, beans and cassava has contracted by $\sim 30,000 \mathrm{~km}^{2}$ (-25\%). That shrinking, however, has been largely compensated by production intensification ${ }^{18}$. In fact all Brazilian crops, and cattle ranching in particular, were subject to a pronounced intensification, well above world averages ${ }^{1,6,10,16,19}$ (Supplementary Fig. 1). Although still inefficient in many regions (mean cattle density $\approx 1$ head per hectare), the stocking density of Brazilian pastures increased $~ 45 \%$ during the 1990-2011 period ${ }^{2,18}$ (Fig. 2c). Increased exports of beef and soybean by $720 \%$ and $530 \%$, respectively ${ }^{1,20}$, and the high share of genetically modified crops in the agricultural matrix (Fig. 2b) are other strong indicators that Brazilian agriculture is turning to an export-oriented large-scale commodity farming pathway.

Intensification of cattle ranching has been widely shown to be the central pivot of the land-use transition to more environmentally friendly agriculture in Brazil ${ }^{5,6,21-24}$, resulting in land being spared for other uses. This option has to be carefully evaluated, however, given that - in light of land rent theor ${ }^{13,25}$ - agricultural intensification and its increased economic attractiveness leads to expansion, rather than contraction of cultivated and grazing land $d^{21,26-28}$. So far Brazil is experiencing the opposite effect, with cattle ranching intensification leading to a reduction, or at least no expansion of total pasture area, along with (governance-driven) declining deforestation rates.

\section{Economic and political conjunctures}

Increases in both domestic and international demand for beef, feed and renewable energy, induced by greater purchase power achieved in Brazil in the past $\sim 15$ years coupled with market liberalization in Russia and China ${ }^{5,10}$, have created new agricultural market opportunities that Brazil and other countries have taken advantage of. However, some factors specific to Brazil made it feasible to intensify agriculture without increasing deforestation.
A convergence of conditions such as internal market regulations, creation of more protected areas, command-andcontrol crack-down on illegal deforestation and credit barriers imposed by the federal government on municipal counties in deforestation frontiers were largely responsible for the decoupling of deforestation and agricultural expansion in the Amazon ${ }^{12,29-32}$. As a consequence of increased enforceable restrictions on illegal deforestation, it is reasonable to assume that land will become a scarce resource in frontier areas ${ }^{21}$, such as in southern Amazonia, which may lead to a positive feedback for agricultural intensification in those regions, a process now observed in highly consolidated agricultural areas of southern Brazil26,33. In such consolidated rural areas, strong intensification of cattle ranching and steps taken by the sugarcane agro-industry to comply with European market requirements ${ }^{34}$, for instance, have been pushing agriculture to set new environmental standards (for example, prevention of illegal deforestation) in large-scale commodity farming.

One of the strongest factors driving the above changes in Brazilian agriculture was the political power exerted by the large-scale agribusiness sector at the National Congress, and often at the state and municipal levels, mainly in the Amazon, Cerrado and Caatinga regions. The rural caucus is the largest elected 'interest group' in the Brazilian Congress at present, having historically held $20-50 \%$ of the voting power in the Congress lower house since the onset of the redemocratization process in late $1980 \mathrm{~s}^{35,36}$. These legislators have, for instance, strongly opposed land redistribution and agrarian reform policies but also influenced the growth of rural credit availability from US\$15 billion in 1990 to US\$75 billion in 2009 (2009 US\$) ${ }^{37}$. That countrywide credit boost allowed heavy investments on agrochemicals for soil improvement in the Cerrado and Amazonian farmland, and the genetic development of cultivars adapted to tropical climates $^{22}$, for example.

It is undisputable that such subsidies to the Brazilian agro-industry contributed to the economic surge in Brazil, as this sector has accounted for $25 \%$ of the country's gross domestic product (GDP) over the past two decades. However, it is worth questioning what societal sectors have benefited from this commoditization process, as Brazil continues to exhibit - along with a few other countries - the worst inequalities anywhere on Earth in terms of income and land ownership distribution ${ }^{38,39}$. 


\section{Box 1 | LUC context within major Brazilian biomes.}

Over $80 \%$ of the expansion in cropland in Brazil from 1990 to 2011 occurred in the Amazon and Cerrado regions ${ }^{18}$. Amazonia and northern portions of the Cerrado are also the only regions where pasture area has increased (at the expense of native vegetation) over the past 20 years ${ }^{18,91}$. Nevertheless, pasture area evolution over that period for the entire country is debatable, with Brazil's official data accounting for a $\sim 13 \%$ reduction (1.78 to 1.53 million $\left.\mathrm{km}^{2}\right)^{18}$, whereas Food and Agriculture Organization (FAO) statistics indicate a $\sim 6 \%$ increase (1.84 to 1.96 million $\mathrm{km}^{2}$ ) restricted to the $1990 \mathrm{~s}^{1}$ (Fig. 2c).

Amazon Region. Since the early 1990s, Brazilian Amazonia entered a renewed phase of colonization and land use, in which tax incentives played a lesser role and profits from logging and largescale agriculture and cattle ranching, as well as low land prices, drove much of the frontier expansion ${ }^{94}$. This process has been supported by government and bilateral investment programs in infrastructure, such as transport facilities and energy provision? ${ }^{7}$. Despite this pressure, there has been a prominent decline in overall deforestation since 2005: from an annual average of $\sim 18,000 \mathrm{~km}^{2}$ in the 1990-2004 period to $\sim 10,500 \mathrm{~km}^{2}$ in $2005-2012$, with the lowest rate ever of $4,571 \mathrm{~km}^{2}$ in 2012 (Fig. 2a) (drivers of this declining deforestation are addressed in the 'Economic and political junctures' section). Pastures for beef production remain the dominant land use, occupying $60 \%$ to $80 \%$ of deforested land ${ }^{22}$ (Fig. 1), with regional cattle numbers reaching more than 50 million ${ }^{18}$ heads since 2004 .

Cerrado Region. Agriculture now occupies nearly 1 million $\mathrm{km}^{2}$ of the Cerrado, or $\sim 50 \%$ of the biome's original extent ${ }^{18,88}$. Cattle ranching is also by far the dominant land use, but a fraction of these pastures has been replaced recently by advancing large-scale mechanized cropping of soybean and sugarcane, for example ${ }^{18,19,95}$. In fact the Cerrado is Brazil's most important beef producing region, hosting the largest extent of pasturelands and $\sim 50 \%$ of the national herd (Fig. 1a). The pronounced conversion of the Cerrado into soybean monoculture over the past two decades was one of the main contributors to the expansion in total cropland area in Brazil (Fig. 2b). However, as in the Amazon, annual deforestation rates are falling from a mean of $\sim 16,000 \mathrm{~km}^{2}$ in early 2000s to $\sim 6,500 \mathrm{~km}^{2}$ in 2010 (Fig. 2a). Yet the high suitability of the Cerrado topography and soils for mechanized agriculture, the reduced number and total extent of protected areas ${ }^{81}$ (Fig. 3b), the lack of a well-established and routinized deforestation surveillance program, and potential leakage pressure resulting from declining deforestation in Amazonia all indicate that the Cerrado will continue to be a principal region of LUC in Brazil ${ }^{14,29,53}$.

Atlantic Forest Region. The Atlantic Forest biome, an extremely threatened biodiversity hotspot, hosts most of Brazil's croplands

\section{Collateral effects on land distribution}

Land distribution is a long-term chronic problem in Brazil. The 2006 national census revealed that nearly $75 \%$ of all agricultural land area $\left(2.3\right.$ million $\left.\mathrm{km}^{2}\right)$ is in the hands of large-scale commodity-oriented farmers, who own only $10 \%$ of all farm land titles in the country. Conversely, the remaining $25 \%$ of farmland is occupied by smallholders, who represent $90 \%$ of all Brazilian rural properties (Fig. 4).

Despite the eventual environmental and socioeconomic gains achieved during the past decade with the technological improvements and policy regulations of Brazil's agricultural sector ${ }^{40}$, the above changes in the land-use system reinforced the historical
(Fig. 1b), and is inhabited by $\sim 125$ million people, including several major metropolitan areas such as São Paulo and Rio de Janeiro. Only $12 \%\left(\sim 160,000 \mathrm{~km}^{2}\right)$ of the original vegetation remains, less than $50 \%$ of which is located in protected areas ${ }^{89,91}$. However, the area of secondary forest has been increasing in some regions, as predicted by forest transition theory for consolidated agricultural frontiers ${ }^{33}$, owing to the widespread transition to mechanized agriculture (which does not operate in steep areas), and to market-driven enforcement of environmental laws (for example, the Forest Code bill). Dominant land uses in the region are large-scale sugarcane farming and cattle ranching ${ }^{19,88}$ with relatively high cattle stocking rates ( $\sim 2$ head per hectare) spread throughout the biome's southwest region ${ }^{2}$. In the state of São Paulo alone, sugarcane cropland increased from $\sim 18,000 \mathrm{~km}^{2}$ in 1990 to $\sim 52,000 \mathrm{~km}^{2}$ in $2011^{18}$. Although most of this recent sugarcane expansion is occurring in previous pasture lands ${ }^{19,44,95}$, it can be argued that the livestock demand once met by these pastures has been at least partly relocated to the Amazon and Cerrado regions (where pastures have expanded at expense of native vegetation $)^{21,44,96}$, even though methods to objectively detect these indirect LUC have yet to be developed ${ }^{97}$.

Caatinga Region. The semi-arid polygon of northeast Brazil known as Caatinga comprises $970,000 \mathrm{~km}^{2}$ of predominantly thorn-scrub vegetation. From a total human population of $\sim 21$ million, $44 \%$ live in the rural areas, relying heavily on smallholder and seasonal agriculture, goat husbandry (the dominant land use along with subsistence cropping) and firewood harvesting (the major driver of deforestation in the region) ${ }^{98}$. Recent irrigation projects have prioritized export-oriented fruit production. However, major impacts due to poor land management, timber extraction, poorly planned irrigation projects and increasing frequency of severe droughts are contributing to the expansion of desertification, with degraded areas accounting for $40,000 \mathrm{~km}^{2}$, leading to consequent loss of biodiversity, carbon stocks and soil structural and chemical properties ${ }^{99}$. Available estimates indicate that annual deforestation occurred at rates of $\sim 5,900 \mathrm{~km}^{2} \mathrm{yr}^{-1}$ over the 1994-2002 period, decreasing after that to $\sim 1,900 \mathrm{~km}^{2}$ in $2009^{15}$ (Fig. 2a).

Pantanal Region. Despite being the most intact biome in Brazil (only 15\% of its original extension has been converted to anthropogenic uses, mostly for cattle ranching ${ }^{91}$, forestry, the construction of hydroelectric dams and navigation are building pressure for LUC in the seasonally flooded Pantanal region. Nevertheless, the region has also experienced a decline in deforestation over the past decade ${ }^{15}$ (Fig. 2a). Marked environmental concerns over the runaway expansion of sugarcane plantations in neighbouring biomes motivated a legal ban prohibiting sugarcane monoculture in the Pantanal (and Amazonia) ${ }^{100}$.

inequality in land ownership. In the 1986-2006 period there was an increase both in the number of large farms and the total area they occupied. The area occupied by farms larger than 1000 ha increased $1.6 \%$ in this period, representing an extra $\sim 170,000 \mathrm{~km}^{2}$ of largeholdings, namely in the Cerrado and Amazonian agricultural frontiers. Moreover, there has been a decrease in the number of small farms and the total area occupied by small-scale farming, particularly in the Caatinga, probably owing to the hardship faced by smallholders in competing with large-scale commodity farming $^{41}$ and voluntary changes in lifestyle. Some consequences of these changes in land distribution are discussed below. 
a
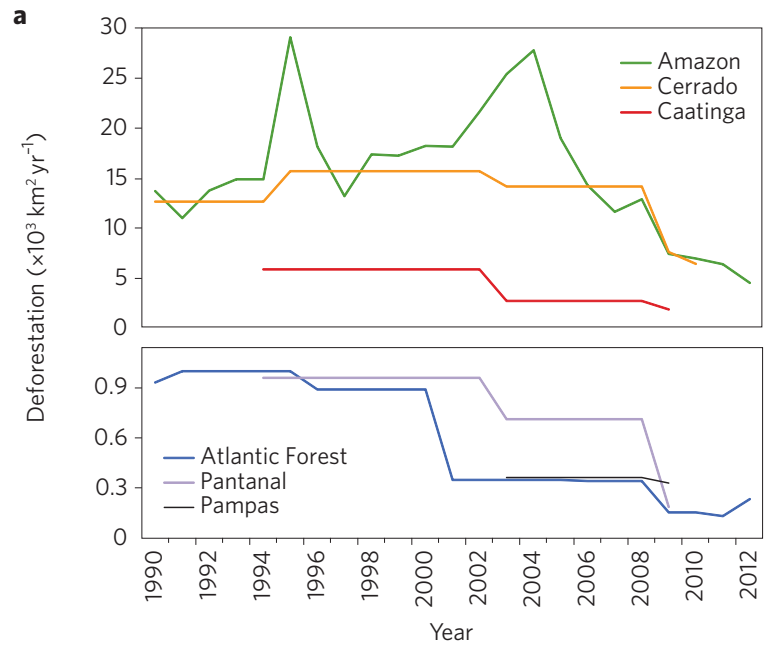

b

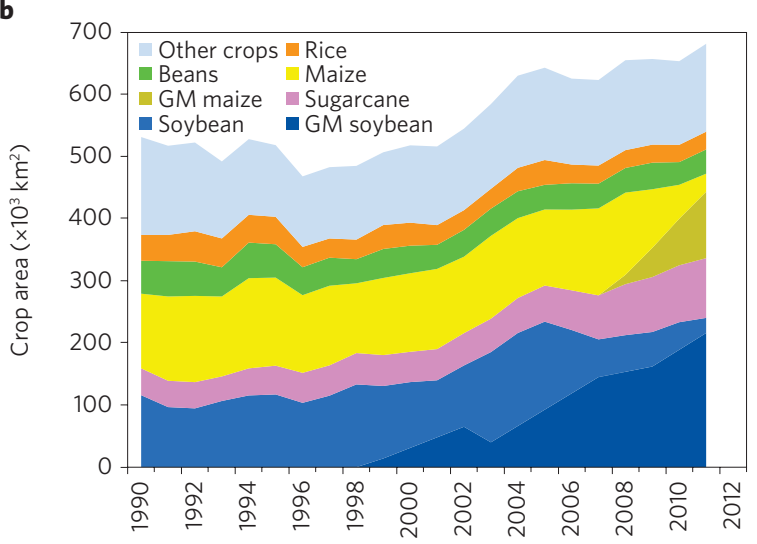

c

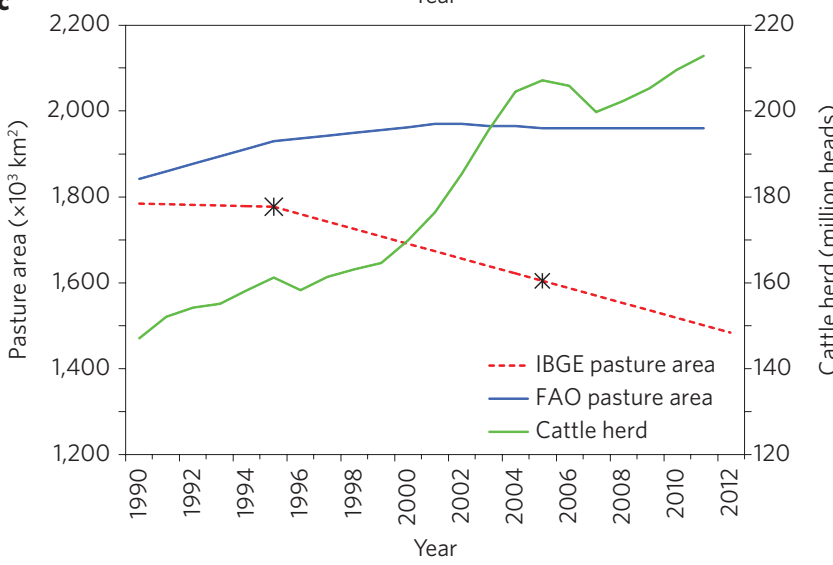

Figure 2 | Trends in land-use change and agricultural expansion in Brazil during the 1990-2012 period. a, Deforestation rates in all Brazilian biomes $3,15,89,90$. Remaining native primary vegetation area in each biome: Amazon: 80\%; Cerrado: 51\%; Caatinga: 54\%; Atlantic Forest: 12\%; Pantanal: 85\%; Pampa: $46 \%{ }^{89,91,92}$. b. Area under each crop type ${ }^{18}$. GM, genetically modified. c, Total pasture area and cattle herd size $\mathrm{e}^{1,18}$; asterisks represent the values provided by Brazil's official census data and the red dashed line indicates the trends between these values.

Food security. Despite the steady shrinkage in overall cropland area allocated to staples such as rice and beans (Fig. 2b), food crop production has increased owing to yield gains (Supplementary Fig. 1), which dismisses scaremongering in projections of food scarcity. However, there could be potential effects on the physical access to food. Although the $4.7 \%$ reduction in the number of smallholdings (Fig. 4a) involved an arable area of only $\sim 12,000 \mathrm{~km}^{2}$, this included over 470,000 individual landholdings. It can therefore be argued that the livelihoods of at least 470,000 households have probably changed with this transition, especially in terms of their financial and physical access to safe food. Nevertheless, increases in per capita income (mainly in the Caatinga owing to short-term welfare policies) ${ }^{40,42}$ suggests that access to food may not have been affected, pending more indepth research.

Rural migration and urbanization. Brazil has become highly urbanized in the past decades, with only $15 \%$ of the entire population now living in rural areas (Supplementary Table 1) as a consequence of both rural exodus driven by capital input into Brazilian agriculture and escalating urban job supply ${ }^{43}$. In fact, this creates a positive feedback in which smaller rural populations lead to lower reliance on human labour in farming ${ }^{22,44,45}$. This is particularly favourable to large-scale mechanized farming, but aggravates the burgeoning population pressure of Brazilian urban areas ${ }^{46}$, which have grown by approximately $400,000 \mathrm{~km}^{2}$ $(+135 \%)$ in the 1992-2010 period (Supplementary Table 1). Urban (instead of rural) population growth was strongly associated with tropical deforestation in the early $2000 \mathrm{~s}^{47}$. Heavily commoditized regions, such as the sugarcane belt in the state of São Paulo, have up to $98 \%$ of the population living in urban areas ${ }^{18}$. Such unplanned urban growth has caused severe environmental and public health problems ${ }^{48}$. This is especially alarming considering that over 11 million Brazilians live in slums with even worse sanitation conditions, and that these people are amongst the most vulnerable to climate change in Brazil ${ }^{49}$.

\section{Interactions with climate change}

While on the one hand land use in Brazil has been reported to be subject and susceptible to global climate change, on the other hand it is also a driver of climatic changes at the local and regional scales. In this section we explore these two-way interactions between land use and climate in Brazil, as well as related changes in GHG emissions.

Coping with the effects of global climate change. Agriculture in Brazil is frequently exposed to the effects of climate extremes. For instance, the 2005 drought in western Amazonia impacted agricultural production and food security ${ }^{50}$; the 2010 floods in southern Brazil destroyed one-seventh of the rice production in the state of Rio Grande do Sul; and climatic adversities in 2010-2011 influenced a sugarcane shortfall that forced the sector to make large imports of ethanol to meet overall demand. Both large-scale farmers and smallholders are vulnerable to these extremes in Brazil today, although the impacts on livelihoods are only undisputable for smallholders ${ }^{51,52}$.

For the future, the government's outlook on agricultural growth singles out global climate change as a large source of uncertainty that will steer the magnitude of production growth in the next decades $^{4}$. Some studies on the impact of future climate change on the yields of crops that are widely cultivated in Brazil consistently point out substantial losses in productivity if no adaptation measures are taken (especially for soybean crops) ) $^{53,54-57}$. The exception is sugarcane, the productivity of which is projected to increase throughout the country. However, fewer studies ${ }^{53,56}$ attempted to quantify how these yield changes could influence land use. In fact, the results of these studies were more relevant to elucidating cause-effect relationships within the Brazilian land system, rather than predicting future land-use patterns. The geography of Brazilian agriculture under future scenarios of climate change therefore remains largely undetermined, given uncertainties regarding the $\mathrm{CO}_{2}$ fertilization effect on crop yields ${ }^{58}$, highly-variable projections of rainfall ${ }^{59}$ and the evolution of both prices and 
a

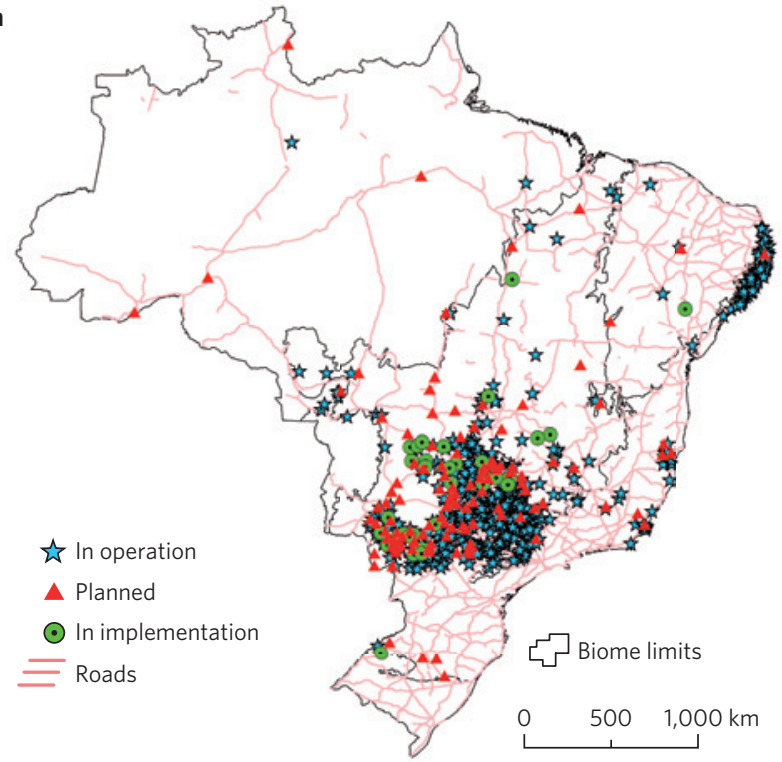

c

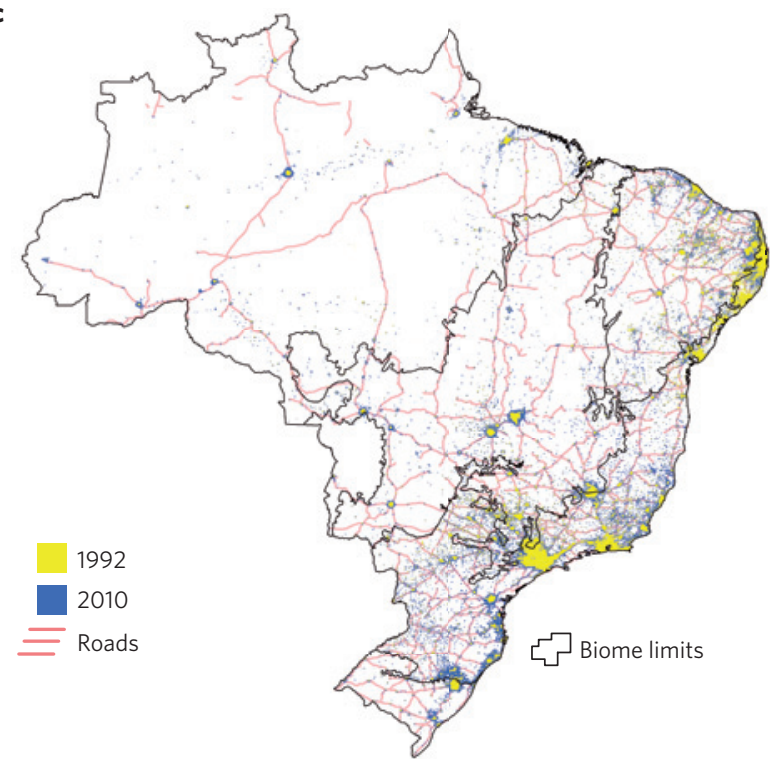

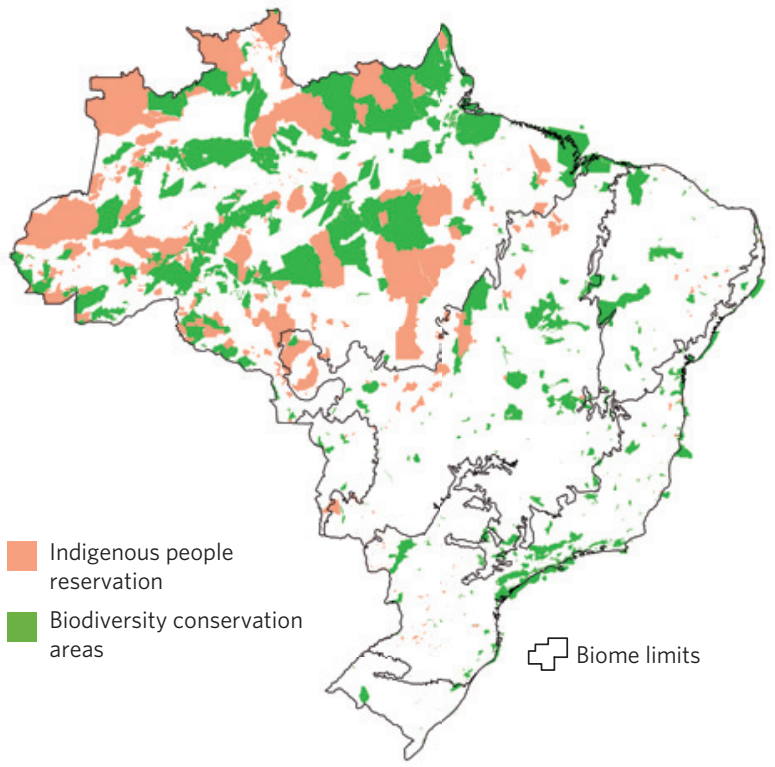

d

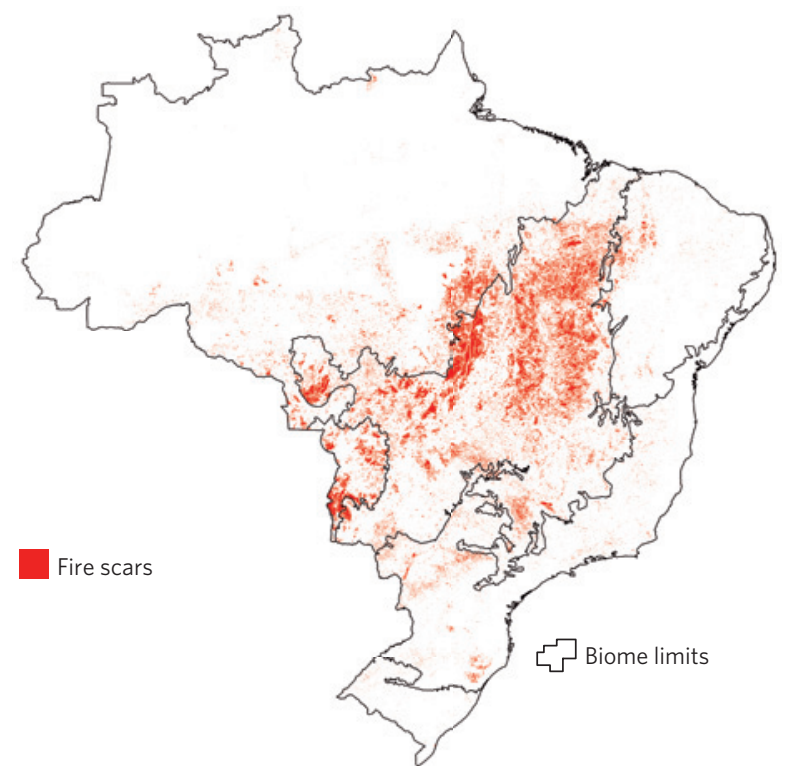

Figure 3 | Biofuels, roads, protected areas and fire in Brazilian biomes. a, Bioenergy (ethanol) plants and road infrastructure ${ }^{5}$. b, Protected areas. c, Urban areas in 1992 and 2010 (as detected from nightlight glow) ${ }^{93}$. d, Fire spots detected in the period 2002-2012 ${ }^{75}$. The scale bar in a applies to all panels.

investments in agricultural adaptation to climate change. As a first-order estimate, 2011 US\$480-570 million should be invested yearly until 2050 to adapt Brazilian agriculture to the ravages of climate change ${ }^{56}$. In light of that, smallholder and subsistence farmers, who are far less economically and institutionally supported than commodity farmers, will certainly be heavily impacted by climate change $e^{51,52}$.

Effects on local and regional climate. Continuing changes in the Brazilian land-use system may also imply alterations in the local and regional climate. Although past studies revealed a local and regional warming originating from forest and savannah conversion into pastures ${ }^{60-62}$, now the encroachment of pastures by commodity crops leads to divergent biosphere-atmosphere relationships. In the Cerrado biome, for example, changes in albedo and evapotranspiration cause an average regional warming of $\sim 1.6^{\circ} \mathrm{C}$ driven by the replacement of the natural vegetation by cropland or pasture, and a cooling of $\sim 0.9^{\circ} \mathrm{C}$ when those pastures are converted to sugarcane fields ${ }^{63,64}$. Conversely, modelling studies suggest that the large-scale substitution of Amazonian pastures by soybean fields will lead to local warming and reduced precipitation compared with pastures. This is due to the marked increase in albedo caused by a decrease in leaf area index, which consequently reduces evapotranspiration in soybean fields between growing seasons $s^{65,66}$. However, the net effect is likely to be a cooling of surface temperatures, considering maize cultivation in the soybean off-season, a prevalent double-cropping system in most Brazilian soybean farms.

Although it is still uncertain whether these changes in land surface properties will lead to regional climatic change, there are indications that they will result in important local and seasonal effects ${ }^{64}$. And importantly, the reduction in deforestation and concomitant maintenance of regional forest-atmosphere heat and moisture fluxes gradually moves the country away from the worst regional climate changes projected from large-scale substitution of Amazonian forests and Cerrado savannahs by pastures and cropland $s^{60,65-67}$ or from degradation of the Caatinga vegetation ${ }^{68}$.

Despite the countrywide reduction in deforestation in the past decade, the number of fire spots detected yearly over the same 


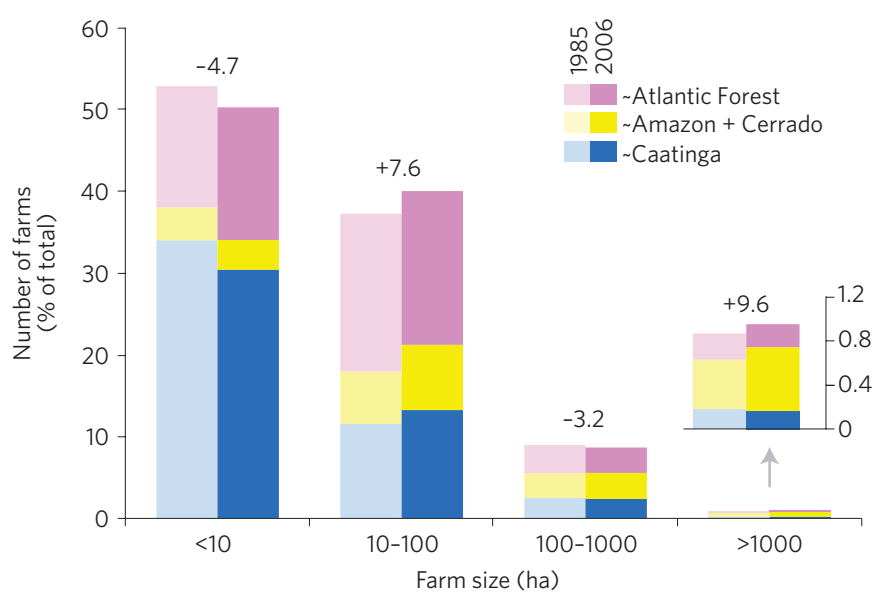

b

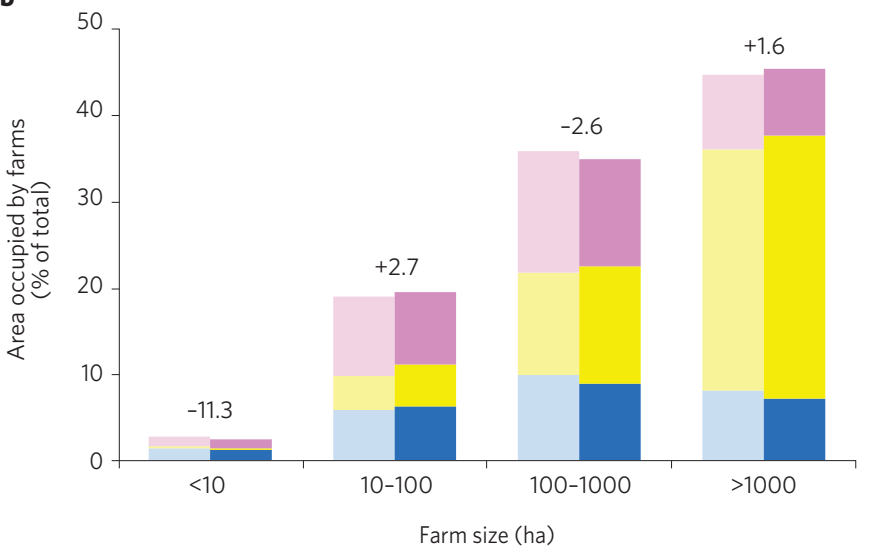

Figure 4 | Evolution of agrarian structure in Brazil between 1985 and

2006. Numbers above the bars denote the percentage change for each period $^{18}$. Atlantic Forest: South+Southeast macro-regions (includes

Pampa biome); Amazon+Cerrado: Centre-West+North (includes Pantanal biome); Caatinga: Northeast (see Supplementary Fig. 2).

period seems to remain largely unchanged ${ }^{69}$. Fires are an important source of aerosols to the atmosphere ${ }^{70}$ that affect the net radiant energy reaching the Earth's surface, interfere in the size of cloud condensation nuclei and rainfall intensity with unintended consequences for the hydrological cycle ${ }^{71}$, and ultimately reverberate back to land use itself.

Moreover, there are also local/regional impacts on other components of the climate system. Compared with pastures, commodity cultivation may lead to soil loss through erosion and requires more pesticide and fertilizer use ${ }^{22}$, which can have a potentially severe impact on freshwater systems (as found in sugarcane areas $^{19}$, but this is still uncertain for Amazonian soybean farms ${ }^{72}$ ) and may also increase GHG emissions released directly by agricultural activities.

Changes in GHG emissions. The last official communication from Brazil to the United Nations Framework Convention on Climate Change reported that the LUC sector emitted $\sim 1200 \mathrm{Tg} \mathrm{CO}_{2} \mathrm{e}$ in 2005 , representing $\sim 20 \%$ of the global $\mathrm{LUC} \mathrm{CO}_{2}$ emissions in that year $^{73}$ and $\sim 60 \%$ of the total Brazilian emissions (Fig. 5a). Most of these LUC emissions were concentrated in the Amazon and Cerrado regions $^{74}$, where most fire hotspots have usually been detected ${ }^{75}$ (Fig. 3d). Preliminary estimates published by Brazil's Ministry of Science, Technology and Innovation $(\mathrm{MCTI})^{76}$ for 2010 reveal a strong shift in the country's emission matrix. With the pronounced countrywide reduction in deforestation, LUC emissions in 2010 were in the order of $280 \mathrm{Tg} \mathrm{CO}_{2} \mathrm{e}$, representing only $20 \%$ of all $\mathrm{CO}_{2} \mathrm{e}$ emissions in the country (Fig. 5b). That reduction in the LUC sector resulted in a decrease of $\sim 40 \%$ in the total Brazilian emissions from 2005 to 2010 (and a reduction of $\sim 10 \%$ from 1990 to 2010).

Emissions from agriculture (including those from limestone application in soils and from energy use for agricultural transport) increased by 45\% from 1990 (320 $\mathrm{Tg} \mathrm{CO}_{2} \mathrm{e}$ ) to 2010 (466 $\mathrm{Tg} \mathrm{CO}_{2} \mathrm{e}$ ). Therefore, agriculture has now replaced the LUC sector for the first time as the leading GHG emitter in Brazil, representing 37\% of all Brazilian emissions (Fig. 5b). Even in a hypothetical, but plausible case in which agricultural emissions are considered to be at the lower estimated limit and LUC emissions at the upper limit, emissions from agriculture would be at least equivalent to those from the LUC sector $\left(2300 \mathrm{Tg} \mathrm{CO}_{2} \mathrm{e}\right)$ in 2010. Most emissions from the agricultural sector originate from cattle ranching $\left(\mathrm{CH}_{4}\right.$ from enteric fermentation and $\mathrm{N}_{2} \mathrm{O}$ from manure decomposition) and to a smaller extent from fertilizer use ${ }^{3}$. In fact, the livestock ranching sector holds a huge potential for mitigating GHG emissions in Brazil ${ }^{77}$.

\section{Shifting to a new land-use paradigm?}

Long-term projections show that food production worldwide is required to increase from $60 \%$ (ref. 8) to $110 \%$ (ref. 78 ) before 2050 to ensure global food security. Brazil is expected to contribute a large fraction of that increased production, given its potential for yield improvements and its large arable land availability ${ }^{8}$. Brazil is one of the few countries on Earth with a reasonable chance to both preserve its biodiversity hotspots and wilderness regions (and even effectively use them in a sustainable way) and operate as an agricultural powerhouse, benefiting from its critical export revenues ${ }^{22}$. If successful, this would inaugurate a new land-use paradigm for tropical countries that are heavily dependent on agriculture, but also safeguard a considerable fraction of the world's biodiversity in intact forests and savannahs. It is therefore crucial that such prospective LUC should be guided by solid sustainability principles, given that climate change, food and energy security, and biodiversity conservation are all at stake. But how could such future land-use be sustainably conducted, and what does sustainable land use mean in the case of Brazil?

Reliance on technological improvements and management practices for agricultural intensification is clearly part of the answer. However, to avoid the side-effects of land-use intensification on environmental degradation, the sector should adopt a toolkit of land management approaches that can convert usual agro-ecosystems into more complex balanced land-use mosaics that resemble natural ecosystems in terms of the services they can provide $^{79}$. These techniques - win-win solutions to avoid soil erosion, build up soil carbon, reduce environmental externalities and ultimately increase productivity - include but are not restricted to: no till, the use of cover crops, elimination of agricultural fires, restoration of vast areas of degraded pastures ${ }^{77}$ and the adoption of integrated crop-livestock-forestry systems. These options have all been long-proposed and comprehensively tested in Brazilian experimental farms ${ }^{80}$ but not yet extensively adopted by the country's farmers.

On the other hand, how do we avoid the lure of agricultural intensification and commoditization, which can drive further pressure on cropland expansion ${ }^{81}$ and displace less capitalized smallholders? The changes seen in the past decade (for instance in Amazonia) reveal that strong governance and sector-oriented policies are a sine qua non condition to prevent that, rather than simply waiting for market self-regulation. In this context, it is extremely important that the Forest Code - a law that regulates the minimum fraction of native vegetation that is set aside within rural properties - and other policies such as the Low-Carbon Agriculture Program are rigorously enforced ${ }^{81,82}$. Although deforestation rates have decreased considerably, the 


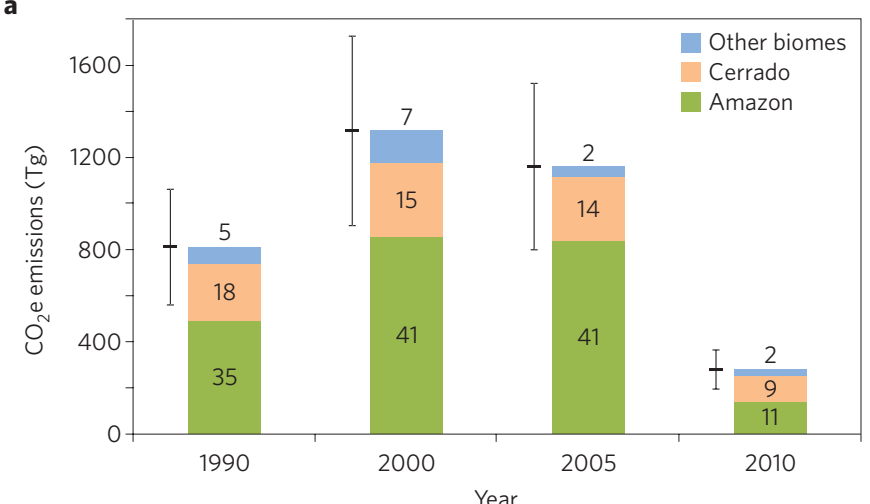

b

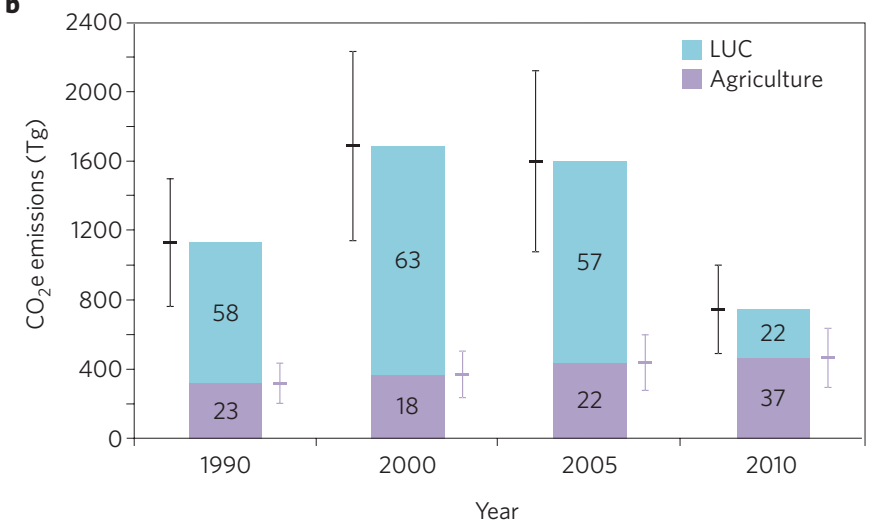

Figure 5 | Greenhouse gas emissions associated with land use in Brazil ${ }^{3,76}$. a, Emissions from land-use change (deforestation) in Brazilian biomes. b, Emissions from agriculture (enteric fermentation, manure decomposition, fertilizer use and other sources) and LUC (deforestation). Numbers inside the bars denote percentage share relative to nationwide total $\mathrm{CO}_{2} \mathrm{e}$ emissions (all sectors) in a given year. Error bars represent estimated uncertainty intervals ${ }^{3}$ for the LUC sector (a), with the agricultural sector indicated in purple and agriculture plus LUC shown in black (b). Agriculture includes emissions from the application of limestone to topsoils and from energy use for agriculture-related transport. The 100-year global warming potential method was used for conversion of $\mathrm{CH}_{4}$ and $\mathrm{N}_{2} \mathrm{O}$ to $\mathrm{CO}_{2} \mathrm{e}$, where 1 $\mathrm{CO}_{2} \mathrm{e}=21 \mathrm{CH}_{4}=310 \mathrm{~N}_{2} \mathrm{O}$.

area of native vegetation in Amazonia and the Cerrado region converted annually into agropastoral land-use is still significant $\left(\sim 12,000 \mathrm{~km}^{2} \mathrm{yr}^{-1}\right)$, and eliminating this residual deforestation solely with the measures employed so far will be a much bigger challenge. Ambitious multi-sectorial integrated governance measures will be needed for that end. An initial movement in this direction is provided by several complementary mechanisms that enable payments for ecosystem services (including REDD+) implemented or under discussion both at the federal and state level, despite several caveats ${ }^{83-85}$.

It has been repeatedly demonstrated that economic development is more effectively achieved by countries with inclusive economic and political institutions ${ }^{86}$. Inclusive economic institutions are those that provide, among other things, safe property rights for all ${ }^{87}$. In Brazil, almost $40 \%$ of smallholders have no land titles, and most of them are located in the Amazon ${ }^{22}$. Property rights for larger farmers are also insecure, mainly owing to perennial conflicts with social minorities such as the landless peasantry or indigenous peoples. Solving long standing problems of land tenure (in both rural and urban areas) is also a milestone on the road to rational land use in Brazil, despite the resistance of successive federal governments to properly address this issue.

In summary, our suggestions for a pathway to sustainable land use in Brazil are: (1) sustainability-oriented land management practices should be widely implemented throughout Brazilian farms; (2) policies furthering this goal should be encouraged and enforced; (3) the Brazilian Forest Code and complementary mechanisms should be strongly enforced, as a way of guaranteeing ecologically equilibrated landscapes that can combine agricultural production and settlements with conservation of natural resources; and (4) long-existing land tenure problems should be solved to bring about property rights security.

We recognize that all of these suggestions are much easier to discuss than implement, given the complexities of institutional and political systems ${ }^{9}$. It is thus critical to understand for the sake of future generations that land use and its economic revenues can become compatible with social welfare and environmental stewardship in Brazil $^{83}$ and other tropical countries. Political institutions and societal organizations in general should be deeply rooted in that mode of thinking, given that sustainable land use in Brazil today means a strong and inextricable combination of technological/management advancements and governance as a way of ensuring that undesirable collateral effects are minimized.

Received 12 September 2013; accepted 28 October 2013; published 20 December 2013.

\section{References}

1. FAOSTAT (FAO, accessed 20 June 2012); http://go.nature.com/E6UaXd

2. Gridded Livestock of the World 2007 (FAO, 2007).

3. Second National Communication of Brazil to the United Nations Framework Convention on Climate Change (Ministério de Ciência e Tecnologia, 2010).

4. Brasil Projeções do Agronegócio 2010-2011 a 2020-2021 (Ministério da Agricultura, Pecuária e Abastecimento, 2011).

5. Plano Decenal de Expansão de Energia 20011/2020 (Empresa de Pesquisa Energética, 2011).

6. Bowman, M. S. et al. Persistence of cattle ranching in the Brazilian Amazon: A spatial analysis of the rationale for beef production. Land Use Policy 29, 558-568 (2012).

7. Killeen, T. J. A Perfect Storm in the Amazon Wilderness, Development and Conservation in the Context of the Initiative for Integration of the Regional Infrastructure of South America (IIRSA) (Conservation International, 2007).

8. Alexandratos, N. \& Bruinsma, J. World Agriculture Towards 2030/2050: The 2012 Revision ESA Working Paper No. 12-03 (FAO, 2012).

9. Geist, H. J. \& Lambin, E. F. Proximate causes and underlying driving forces of tropical deforestation. BioScience 52, 134-150 (2002).

10. Nepstad, D. C., Stickler, C. M. \& Almeida, O. T. Globalization of the Amazon soy and beef industries: Opportunities for conservation. Conserv. Biol. 20, 1595-1603 (2006).

11. Gibbs, H. K. et al. Tropical forests were the primary sources of new agricultural land in the 1980s and 1990s. Proc. Natl Acad. Sci. USA 107, 16732-16737 (2010).

12. Macedo, M. N. et al. Decoupling of deforestation and soy production in the southern Amazon during the late 2000s. Proc. Natl Acad. Sci. USA 109, 1341-1346 (2012).

13. Angelsen, A. Policies for reduced deforestation and their impact on agricultural production. Proc. Natl Acad. Sci. USA 107, 19639-19644 (2010).

14. Ferreira, N. C., Ferreira, L. G. Jr, Huete, A. R. \& Ferreira, M. E. An operational deforestation mapping system using MODIS data and spatial context analysis. Int. J. Remote Sens. 28, 47-62 (2007).

15. Satellite Monitoring of Deforestation in Brazilian Biomes Program (IBAMA, accessed 25 February 2012); http://siscom.ibama.gov.br/monitorabiomas

16. Valor Bruto da Produção: 2003-2012 (MAPA, 2012).

17. Censo Agropecuário 2006 - Primeiros Resultados: Agricultura Familiar Brasil, Grandes Regiões e Unidades da Federação (IBGE, 2009).

18. Municipal Agricultural Production and Population Census (Instituto Brasileiro de Geografia e Estatística, 2012); http://go.nature.com/vdm5lC

19. Martinelli, L. A. \& Filoso, S. Expansion of sugarcane ethanol production in Brazil: Environmental and social challenges. Ecol. Appl. 18, 885-898 (2008).

20. Exportação por Ano (ABIEC, accessed 9 September 2013); http://go.nature.com/nWyozz

21. Barretto, A. G. O. P., Berndes, G., Sparovek, G. \& Wirsenius, S. Agricultural intensification in Brazil and its effects on land-use patterns: An analysis of the 1975-2006 period. Glob. Change Biol. http://dx.doi.org/10.1111/gcb.12174 (2013). 
22. Martinelli, L. A., Naylor, R., Vitousek, P. M. \& Moutinho, P. Agriculture in Brazil: Impacts, costs, and opportunities for a sustainable future. Curr. Opin. Environ. Sustain. 2, 431-438 (2010).

23. Regulamenta os Arts. 6, 11 e 12 da Lei no 12.187, de 29 de Dezembro de 2009, que Institui a Política Nacional sobre Mudança do Clima: PNMC, e dá Outras Providências Federal Decree 7.390/2010 (Government of Brazil, 2010).

24. Cohn, A., Bowman, M., Zilberman, D. \& O'Neill, K. The Viability of Cattle Ranching Intensification in Brazil as a Strategy to Spare Land and Mitigate Greenhouse Gas Emissions (CGIAR Research Program on Climate Change, Agriculture and Food Security, 2011).

25. Kaimowitz, D., Angelsen, A. Will livestock intensification help save Latin America's tropical forest? J. Sustain. For. 27, 6-24 (2008)

26. Rudel, T. K. et al. Agricultural intensification and changes in cultivated areas, 1970-2005 Proc. Natl Acad. Sci. USA 106, 20675-20680 (2009)

27. Balmford, A., Green, R. E., Scharlemann, J. P. W. Sparing land for nature: Exploring the potential impact of changes in agricultural yield on the area needed for crop production. Glob. Change Biol. 11, 1594-1605 (2005).

28. Lambin, E. F. \& Meyfroidt, P. Global land use change, economic globalization, and the looming land scarcity. Proc. Natl Acad. Sci. USA 108, 3465-3472 (2011).

29. Nepstad, D. et al. The end of deforestation in the Brazilian Amazon. Science 326, 1350-1351 (2009).

30. Rudorff, B. F. T. et al. The soy moratorium in the Amazon biome monitored by remote sensing images. Remote Sens. 3, 185-202 (2011).

31. Walker, R. et al. Protecting the Amazonia with protected areas. Proc. Natl Acad. Sci. USA 106, 10582-10586 (2009).

32. Assunção, J. A., Gandour, C. C. \& Rocha, R. Deforestation Slowdown in the Legal Amazon: Prices or Policies? (Climate Policy Initiative, 2012).

33. Walker, R. The scale of forest transition: Amazonia and the Atlantic forests of Brazi. Appl. Geogr. 32, 12-20 (2012).

34. Directive 2009/28/CE of the European Parliament and Council, of 23 April 2009, on the Promotion of the Use of Energy from Renewable Sources and Amending and Subsequently Repealing Directives 2001/77/EC and 2003/30/EC (EU, 2009).

35. Wolford, W. Participatory democracy by default: Land reform, social movements and the state in Brazil. J. Peasant Stud. 37, 91-109 (2010)

36. Costa, S. H. G. A Questão Agrária no Brasil e a Bancada Ruralista no Congresso Nacional Masters dissertation, Univ. de São Paulo (2012).

37. Ramos, S. Y \& Martha-Júnior, G. B. Evolução da Política de Crédito Rural Brasileira (Embrapa, 2010).

38. Abbey, L. A., Baer, B. \& Filizzola, M. Growth efficiency, and equity: The impact of agribusiness and land reform in Brazil. Lat. Am. Bus. Rev. 7, 93-115 (2006).

39. Ferreira, F. G. H., Leite, P. G. \& Litchfield, J. A. The Rise and Fall of Brazilian Inequality: 1981-2004 Policy Research Working Paper 3867 (World Bank, 2006).

40. VanWey, L. K., Spera S., de Sa, R., Mahr, D. \& Mustard, J. F. Socioeconomic development and agricultural intensification in Mato Grosso. Phil. Trans. R. Soc. B. 368, 20120168 (2013).

41. Martinelli, L. A., Joly, C. A., Nobre, C. A. \& Sparovek, G. The false dichotomy between preservation of the natural vegetation and food production in Brazil. Biota Neotrop. 10, 323-330 (2010).

42. Índice de Desenvolvimento Humano Municipal Brasileiro (PNUD, 2013).

43. Perz, S. G. The rural exodus in the context of economic crisis, globalization and reform in Brazil. Int. Migr. Rev.

131, 842-881 (2000).

44. Aguiar, D. A., Rudorff, B. F. T., Silva, W. F., Adami, M. \& Mello, M. P. Remote sensing images in support of environmental protocol: monitoring the sugarcane harvest in São Paulo state, Brazil. Remote Sens 3, 2682-2703 (2011).

45. Lambin, E. F. et al. Estimating the world's potentially available cropland using a bottom-up approach. Glob. Environ. Change http://dx.doi.org/10.1016/j. gloenvcha.2013.05.005 (2013)

46. Mata, D., Deichmann, U., Henderson, J. V., Lall, S. V. \& Wang H. G. Determinants of City Growth in Brazil (National Bureau of Economic Research, 2005).

47. DeFries, R. S., Rudel, T., Uriarte, M. \& Hansen, M. Deforestation driven by urban population growth and agricultural trade in twenty-first century. Nature Geosci. 3, 178-181 (2010).

48. Hotez, P. J. Forgotten Diseases, Forgotten People: The Neglected Tropical Diseases and Their Impact on Global Health and Development (ASM, 2008).

49. Torres, R. R., Lapola, D. M., Marengo, J. A. \& Lombardo, M. A. Socio-climatic hotspots in Brazil. Climatic Change 115, 597-609 (2012).

50. Marengo, J. A. et al. The drought of Amazonia in 2005. J. Clim. 21, 495-516 (2008)

51. Morton, J. F. The impact of climate change on smallholder and subsistence agriculture. Proc. Natl Acad. Sci. USA 104, 19680-19685 (2007).

52. Brondizio, E. S. \& Moran, E. F. Human dimensions of climate change: The vulnerability of small farmers in the Amazon. Phil. Trans. R. Soc. B 363, 1803-1809 (2008).
53. Lapola, D. M. et al. Impacts of climate change and the end of deforestation on land use in the Brazilian Legal Amazon. Earth Interact.

15, 1-29 (2011)

54. Lobell, D. B. et al. Prioritizing climate change adaptation needs for food security in 2030. Science 319, 607-610 (2008).

55. Assad, E. \& Pinto, H. S. (eds) Aquecimento Global e a Nova Geografia da Produção Agrícola no Brasil (EMRAPA and UNICAMP, 2008).

56. Margulis, S., Dubeux, C. B. S. \& Marcovitch, J. (Technical coordinators) The Economics of Climate Change in Brazil: Costs and Opportunities (FEA/USP, 2011).

57. Oliveira, L. J. C., Costa, M. H., Soares-Filho, B. S. \& Coe, M. Large-scale expansion of agriculture in Amazonia may be a no-win scenario. Environ. Res. Lett. 8, 024021 (2013).

58. Lobell, D. B. \& Field, C. B. Estimation of the carbon dioxide $\left(\mathrm{CO}_{2}\right)$ fertilization effect using growth rate anomalies of $\mathrm{CO}_{2}$ and crop yields since 1961 . Glob. Change Biol. 14, 39-45 (2008).

59. Torres, R. R. \& Marengo, J. A. Uncertainty assessments of climate projections over South America. Theor. Appl. Climatol. 112, 253-272 (2013).

60. Nobre, C. A., Sellers, P. \& Shukla, J. Amazonian deforestation and regional climate change. J. Climate 4, 957-988 (1991)

61. Negri, A. J., Adler, R. F., Xu, L. \& Surratt, J. The impact of Amazonian deforestation on dry season rainfall. J. Clim. 17, 1306-1319 (2004).

62. Malhado, A. C. M., Pires, G. F. \& Costa, M. H. Cerrado conservation is essential to protect the Amazon rainforest. Ambio 39, 580-584 (2010).

63. Loarie, S. R., Lobell, D. B., Asner, G. P., Mu, Q. \& Field, C. B. Direct impacts on local climate of sugar-cane expansion in Brazil. Nature Clim. Change 1, 105-109 (2011)

64. Georgescu, M., Lobell, D. B., Field, C. B. \& Mahalov, A. Simulated hydroclimatic impacts of projected Brazilian sugarcane expansion. Geophys. Res. Lett. http://dx.doi.org/10.1029/2012GL054612 (2013).

65. Costa, M. H., Yanagi, S. N. M., Souza, P. J. O. P., Ribeiro, A. \& Rocha, E. J. P. Climate change in Amazonia caused by soybean cropland expansion, as compared to caused by pastureland expansion. Geophys. Res. Lett. 34, L07706 (2007)

66. Sampaio, G. et al. Regional climate change over eastern Amazonia caused by pasture and soybean cropland expansion. Geophys. Res. Lett. 34. L17709 (2007).

67. Costa, M. H. \& Foley, J. A. Combined effects of deforestation and doubled atmospheric $\mathrm{CO}_{2}$ concentrations on the climate of Amazonia. J. Clim. 13, 18-34 (2000).

68. Souza, D. C. \& Oyama, M. D. Climatic consequences of gradual desertification in the semi-arid area of Northeast Brazil. Theoretical and Applied Climatology 103, 345-357 (2011)

69. Monitoring of Vegetation Fires (INPE, accessed 6 December 2013); http://go.nature.com/pFbvTz

70. Lara, L. L. et al. Properties of aerosols from sugar cane burning emissions in Southern Brazil. Atmos. Environ. 39, 4627-4637 (2005).

71. Rosenfeld, D. et al. Flood or drought: How do aerosols affect precipitation? Science 321, 1309-1313 (2008)

72. Neill, C. et al. Watershed responses to Amazon soya bean cropland expansion and intensification. Phil. Trans. R. Soc. B 368, 20120425 (2013)

73. Le Quéré, C. et al. Trends in the sources and sinks of carbon dioxide. Nature Geosci. 2, 831-836 (2009)

74. Aguiar, A. P. D. et al. Modeling the spatial and temporal heterogeneity of deforestation-driven carbon emissions: the INPE-EM framework applied to the Brazilian Amazon. Global Change Biol. 18, 3346-3366 (2012).

75. Araújo, F. M., Ferreira, L. G. \& Arantes, A. E. Distribution patterns of burned areas in the Brazilian biomes: an analysis based on satellite data for the 2002-2010 period. Remote Sens. 4, 1929-1946 (2012).

76. Estimativas Anuais de Emissões de Gases de Efeito Estufa no Brasil (MCTI, 2013).

77. Bustamante, M. M. C. et al. Estimating greenhouse gas emissions fom cattle raising in Brasil. Climatic Change 115, 559-577 (2012).

78. Tilman, D., Balzer, C., Hill, J. \& Befort, B. L. Global food demand and the sustainable intensification of agriculture. Proc. Natl. Acad. Sci. USA 108, 20260-20264 (2011).

79. Godfray, H. C. J. et al. Food security: the challenge of feeding 9 billion people. Science 327, 812-818 (2010).

80. Bungestab, D. M. (ed.) Sistemas de Integração Lavoura-pecuária-floresta: A Producão Sustentável (Embrapa, 2012).

81. Sparovek, G. et al. Brazilian agriculture and environmental legislation: Status and future challenges. Environ. Sci. Technol. 4, 6046-6053 (2010).

82. Angelo, C. Brazil's fund for low-carbon agriculture lies fallow. Nature News http://dx.doi.org/10.1038/nature.2012.11111 (2012).

83. Galford, G. L., Soares-Filho, B. \& Cerri, C. E. P. Opinion piece: Prospects for land-use sustainability on the agricultural frontier of the Brazilian Amazon. Phil. Trans. R. Soc. B. 368, 20120171 (2013).

84. Wunder, S. 2007. The efficiency of payments for environmental services in tropical conservation. Conserv. Biol. 21, 48-58 (2007). 
85. Moutinho, P. et al. The emerging REDD+ regime of Brazil. Carbon Manage. 2, 587-602 (2011).

86. Acemoglu, D. \& Robinson, J. Why Nations Fail: The Origins of Power, Prosperity, and Poverty (Crown Business, 2012).

87. Sen, K. The political dynamics of economic growth. World Dev. 47, 71-86 (2013).

88. Monfreda, C., Ramankutty, N. \& Foley, J. A. Farming the planet: 2. Geographic distribution of crop areas, yields, physiological types, and NPP in the year 2000. Global Biogeochem. Cycles 22, GB1022 (2008).

89. Atlas of the Atlantic Forest Remnants: 2010-2011 Period (SOS Mata Atlântica \& INPE, 2012).

90. PRODES (INPE, accessed 20 February 2012); http://www.obt.inpe.br/prodes

91. Indicadores do Desenvolvimento Sustentável - Brasil 2012 (IBGE, 2012).

92. TerraClass Land-use Database (INPE, accessed 10 September 2013); http://go.nature.com/fIAFXg

93. Defense Meteorological Satellite Program 2013 (Department of Defense, accessed 10 September 2013); http://go.nature.com/u7b6Os

94. Margulis, S. Causas do Desmatamento na Amazônia Brasileira (The World Bank, 2003).

95. Walter, A. et al. Sustainability assessment of bio-ethanol production in Brazil considering land use change, GHG emissions and socio-economic aspects. Energy Policy 39, 5703-5716 (2011).

96. Lapola, D. M. et al. Indirect land-use changes can overcome carbon savings from biofuels in Brazil. Proc. Natl Acad. Sci. USA 107, 3388-3393 (2010).

97. Arima, E. Y., Richards, P., Walker, R. \& Caldas, M. M. Statistical confirmation of indirect land use change in the Brazilian Amazon. Environ. Res. Lett. 6, 024010 (2011).
98. Sampaio, E. et al. Tree biomass estimation in regenerating areas of tropical dry vegetation in northeast Brazil. Forest Ecology and Management 259, 1135-1140 (2010).

99. Sampaio, E. V. S. B., Araújo, M. S. B. \& Sampaio, Y. Propensão à desertificação no semi-árido brasileiro. Rev. Geogr. 22, 67-80 (2005).

100. Aprova o Zoneamento Agroecológico da Cana-de-açúcar e Determina ao Conselho Monetário Nacional o Estabelecimento de Normas para as Operações de Financiamento ao Setor Sucroalcooleiro, nos Termos do Zoneamento Federal Decree 6.961/2009 (Government of Brazil, 2009).

\section{Acknowledgements}

We thank E.L. Dalla Nora, A.O. Manzi and K.-H. Erb for their helpful comments on the manuscript.

\section{Author Contributions}

D.M.L., L.A.M., C.A.P., J.P.H.B.O., M.E.F. and C.A.N. designed the research. All authors contributed to the writing.

\section{Additional information}

Supplementary information is available in the online version of the paper. Reprints and permissions information is available online at www.nature.com/reprints. Correspondence should be addressed to D.M.L.

\section{Competing financial interests}

The authors declare no competing financial interests. 